\title{
Anaplasma phagocytophilum in horses and ticks in Tunisia
}

Youmna M'ghirbi ${ }^{1,2}$, Hèla Yaïch ${ }^{3,4}$, Abderazek Ghorbel $^{3,4}$ and Ali Bouattour ${ }^{1,2^{*}}$

\begin{abstract}
Background: Anaplasma phagocytophilum, the causative agent of granulocytic anaplasmosis, affects several species of wild and domesticated mammals, including horses. We used direct and indirect methods to compare and evaluate exposure to A. phagocytophilum in horses in northern Tunisia.

Methods: Serum from 60 horses was tested by IFA for antibodies to A. phagocytophilum, and whole blood was tested for A. phagocytophilum $16 \mathrm{~S}$ rRNA gene using a nested-PCR. To examine the risk of A. phagocytophilum transmission, 154 ticks that had been collected from horses were examined for the presence of A. phagocytophilum by nested-PCR targeting $16 \mathrm{~S}$ rRNA gene.

Results: This is the first time that A. phagocytophilum has been detected in horses in Tunisia, with an overall seroprevalence of 40/60 (67\%). Six of the seroreactive samples (10\%) had an IFA titer of 1:80, 14 (23\%) of 1:160, 8 (13\%) of $1: 320$ and $12(20 \%)$ a titer $1 \geq 640$. The seroprevalence revealed no significant regional and sex differences. In contrast, a significant difference was observed between breeds. Eight (13\%) of the horses were positive for $A$. phagocytophilum in the PCR, with no significant breed and age differences. Hyalomma marginatum was a predominant tick species (130/154), and 3 were infected by A. phagocytophilum (a prevalence of 2.3\%). The concordance rate of $A$. phagocytophilum detection between IFA and PCR had a $k$ value of -0.07 .
\end{abstract}

Conclusions: The results presented in this study suggest that horses infested by ticks in Tunisia are exposed to $A$. phagocytophilum.

Keywords: Anaplasma phagocytophilum, Horses, Ticks, 165 rRNA gene, nPCR, IFA, Tunisia

\section{Background}

Three former species of granulocytic bacteria, Ehrlichia phagocytophila, Ehrlichia equi and the agent of human granulocytic ehrlichiosis, are considered as one and the same species and have been renamed as Anaplasma phagocytophilum following the reorganization of the Anaplasmataceae and Rickettsiaceae families in the order Rickettsiales [1]. Anaplasma phagocytophilum, etiologic agent of the formerly called equine granulocytic ehrlichiosis, is now reported as equine granulocytic anaplasmosis (EGA), and was first recognized as an equine disease in California [2]. The disease was subsequently found in other parts of the US and in Europe [3-6]. The most common symptoms include fever, depression, lack of appetite, leg swelling,

\footnotetext{
* Correspondence: ali.bouattour@pasteur.rns.tn

'Laboratoire d'épidémiologie et microbiologie vétérinaire, service d'entomologie médicale, Institut Pasteur de Tunis, Tunis 1002, Tunisia

Université Tunis El-Manar, Tunis, Tunisia

Full list of author information is available at the end of the article
}

reluctance to move and yellowish gums. A. phagocytophilum is maintained in a zoonotic cycle between infected mammalian host reservoirs and ticks, mainly (or perhaps only) those of the Ixodes ricinus and I. persulcatus complex [7].

In North Africa (Morocco, Algeria and Tunisia), Ixodes ricinus seems to be the main (or perhaps only) vector, although Hyalomma detritum might also play a role in transmitting A. phagocytophilum to cattle [8]. Moreover, A. phagocytophilum is likely to circulate in a variety of ticks as they feed on dogs or reptiles, as observed in Tunisia, South Africa and Ghana [9,10], although it is unknown whether they can transmit it.

To our knowledge, no information is available regarding the presence of $A$. phagocytophilum in horses and ticks in Tunisia. The present study was undertaken to further elucidate some epidemiological aspects of this vectorial disease. We investigated the exposure of horses in Tunisia to this bacterium by using an indirect 
fluorescent antibody (IFA) test to detect reactive antibodies against $A$. phagocytophilum, and molecular methods (nested polymerase chain reaction, nPCR) to detect the DNA. In addition, the latter assay was used to detect A. phagocytophilum in Ixodid ticks infesting horses.

\section{Methods}

\section{Study areas and blood samples}

Between April and June 2008, sixty horses were identified from 4 different localities all in a humid bioclimatic zone: Sejnane $\quad\left(\mathrm{n}=15 ; \quad 37^{\circ} 03^{\prime} 29.85^{\prime \prime} \mathrm{N} \quad 9^{\circ} 14^{\prime} 20.80^{\prime \prime} \mathrm{E} ; \quad\right.$ altitude $200 \mathrm{~m})$, Tabarka ( $\mathrm{n}=5 ; 36^{\circ} 57^{\prime} 26.51^{\prime \prime} \mathrm{N} 8^{\circ} 45^{\prime} 03.95^{\prime \prime} \mathrm{E}$; altitude 700 m), Aïn Draham $\left(\mathrm{n}=10 ; 36^{\circ} 46^{\prime} 48.97^{\prime \prime} \mathrm{N} 8^{\circ} 41^{\prime} 13.73^{\prime \prime} \mathrm{E}\right.$; altitude $800 \mathrm{~m})$ and Ghardimaou $\left(\mathrm{n}=30 ; 36^{\circ} 26^{\prime} 58.43^{\prime \prime} \mathrm{N} 8^{\circ}\right.$ $26^{\prime} 10.59$ "E, altitude $250 \mathrm{~m}$ ). Within each region, horses were selected randomly based on availability due to previous contact to individual horse owners and clinical veterinary practices. Favorable to Ixodes ricinus tick, this bioclimatic zone is characterized by oak forests (Quercus faginea and Q. suber) with an undergrowth of ferns (predominantly Pteridium aquilinum) and tree heather (Erica arborea) [11]. Local fauna is a mixture of domestic (cattle, sheep, goats and horses) and wild animals, mainly lizards (Psammodromus algirus), wild boar and several species of birds (Erithacus rubecula, Turdus merula).

The age, sex and relative degree of tick infestation of each horse were recorded. All horses studied were born in Tunisia and have not traveled outside the country. Five milliliters of venal blood were collected from a jugular vein of each horse and an aliquot of $1 \mathrm{ml}$ was placed in an EDTAtube, for nPCR analysis. The rest of the collected blood samples were placed in coagulant-free tubes and allowed to clot at room temperature $\left(25^{\circ} \mathrm{C}\right)$. Samples were centrifuged at $2500 \mathrm{rpm}$ for $15 \mathrm{~min}$ and sera removed and stored at $-20^{\circ}$ $\mathrm{C}$ for the IFA tests. Our survey did involve sampling of a minimal number of horses according to internationally recognized guidelines with the approval of the Human and animal Ethics Committee of Pasteur Institute of Tunis.

\section{Tick collection}

Ticks were collected systematically from each horse, beginning at the head and neck region, then the pectoral, axillary and inguinal regions, finishing at the tail. The ticks were placed in a single container and preserved in $70 \%$ ethanol. Adult ticks were identified to the species level using a published taxonomic key [12].

\section{Serologic analysis}

Samples were screened for IgG against $A$. phagocytophilum using a commercially available IFA assay from Fuller Laboratories (US). This IFA assay utilizes $A$. phagocytophilum-infected HL60 cells. All samples were tested at a 1:80 as starting dilution in phosphatebuffered saline solution (PBS), as per the manufacturer's protocol. The resulting reactions were visualized using standard fluorescence microscopy $(400 \times)$, where a positive reaction appears as sharply defined apple-green fluorescent inclusions (A. phagocytophilum morulae) in the cytoplasm of infected cells. A negative reaction appears as either red-counterstained cells or fluorescence unlike that seen in the positive control wells. Horse seropositive samples were then analyzed to determine the titration end point and the antibody titers were summarized into four different groups: 1:80, 1:160, $1: 320,>1: 640$. A positive and a negative serum control, provided in the kit, were added to each slide.

\section{DNA extraction and nested-PCR}

DNA was extracted from $200 \mu \mathrm{L}$ of horse blood and unfed adult ticks, using Dneasy Tissue Kit (Qiagen Inc., Germany) as per the manufacturer's instructions, eluted with $90 \mu \mathrm{L}$ of $\mathrm{AE}$ buffer and then stored at $-20{ }^{\circ} \mathrm{C}$ until further use. DNA yields were determined with a NanoDrop ${ }^{\circledR}$ ND-1000 Spectrophotometer (NanoDrop Technologies, DE, USA).

Genomic DNA of $A$. phagocytophilum was amplified by nested-PCR (nPCR) using the 16S subunit rDNA gene primers described by Massung et al. [13]. The first PCR amplification of $A$. phagocytophilum agent was performed in a 25 $\mu \mathrm{L}$ reaction mixture containing $3 \mu \mathrm{L}$ of each DNA template with ge3a (5'-CACAATGCAAGTCGAACGGATTATTC3') and ge10r (5'-TTCCGTTAAGAAGGATCTAATCTCC3') to amplify $919 \mathrm{bp}$ of the $16 \mathrm{~S}$ rRNA gene of A. phagocytophilum complex. Reaction conditions were as follows: $0.2 \mu \mathrm{M}$ each primer, $200 \mu \mathrm{M}$ each deoxynucleoside triphosphate (Amersham Pharmacia biotech, UK), $1.25 \mathrm{U}$ of Taq polymerase (Amersham Pharmacia biotech, UK) and $1 \times$ Taq buffer $(1.25 \mathrm{mM} \mathrm{MgCl} 2)$. The reactions were performed on an automated DNA thermal cycler (Perkin-Elmer 2400, CA) under the following conditions: initial denaturation at $93{ }^{\circ} \mathrm{C}$ for $1 \mathrm{~min}$, annealing at $55{ }^{\circ} \mathrm{C}$ for $5 \mathrm{~min}$ and extension at $72{ }^{\circ} \mathrm{C}$ for $30 \mathrm{~s}$. The first PCR product from each sample was then diluted 1:10 with distilled water and $3 \mu \mathrm{L}$ of the diluted solution were used as the template DNA for the second PCR in a final volume of $25 \mu \mathrm{L}$. Species-specific amplification primers ge9F (5'-AACGGATTATTCTTTA TAGCTTGCT-3') and ge2 (5'-GGCAGTATTAAAAG CAGCTCCAGG-3') were used to amplify a 546 bp portion from the $5^{\prime}$ region of the $16 \mathrm{~S}$ rRNA gene to identify $A$. phagocytophilum. The other PCR conditions were the same as in the first PCR. Positive and negative quality controls were also included with each experiment. DNA extracted from $A$. phagocytophilum (kindly provided by D. Postic, Pasteur Institute of Paris) was used as positive control.

\section{DNA sequencing and data analysis}

To confirm the nPCR results, positive A. phagocytophilum amplified DNA was analyzed by sequencing using 
species-specific primers as described previously [13]. The PCR products were purified using the ExoSAP cleanup procedure (Amersham Biosciences). All nucleotide sequences were obtained using the Big Dye Terminator v.3.1 Cycle Sequencing Kit (Applied Biosystems) and the 3130 automated sequencer (Applied Biosystems). The sequences generated in this study have been deposited in the GenBank database under accession numbers JX121282-JX121291 (Table 1) and then edited and aligned using the software programs BioEdit [14] and ClustalW [15]. The BLAST program (http://www. ncbi.nlm.nih.gov/BLAST) was used to compare and analyze the data sequences.

\section{Statistical analysis}

IFA test results were compared with nPCR findings; the two methods were assessed with a concordance test, and a Cohel $k$ value was calculated [16]. Chi-square test, done with a commercially available statistical program (EpiInfo 6.01), was used. Observed differences were considered to be significant when the resulting $\mathrm{p}$ value was less than 0.05 .

\section{Results}

\section{Horse population and tick collection}

During the study, 60 horses from humid bioclimatic zones were examined: 29 Arabian horses and 31 of the Barb breed. The horses were 12 years old on average (range of 2-28 years). Age was classified into four groups of 1-4 years, 5-10 years, 11-20 years and over 21 years. The adult ticks collected from the horses ( $\mathrm{n}=243$ ) were classified as Hyalomma marginatum (144 males and 72 females), $H$. excavatum (17 males and 2 females) and Rhipicephalus bursa (4 males and 4 females). Only 11 of the $60(18 \%)$ of the examined horses were infested by at least one of these tick species.

\section{Serological test}

An indirect fluorescence assay showed that sera of $67 \%$ of the analysed horse population reacted with A. phagocytophilum antigen. Horses $(\mathrm{n}=30)$ from Sejnane, Aïn Draham and Tabarka had a high rate of A. phagocytophilum antibodies (80\%). In Ghardimaou, the seroprevalence was 53\%. Titration endpoints for $A$. phagocytophilum ranged from 1:80 to $1 \geq 640$. Six of the positive samples (10\%) had an IFA titer of 1:80, 14 (23\%) of $1: 160,8(13 \%)$ of $1: 320$ and $12(20 \%)$ of $1 \geq 640$. A. phagocytophilum seroprevalence of horses revealed nonsignificant regional $(\chi 2=4.8 ; \mathrm{ddl}=3 ; \mathrm{P}>0.05)$ and sex $\left(\chi_{2}=0 ; \mathrm{P}=1\right)$ differences but a significant breed difference $(\chi 2=16.59 ; \mathrm{P}<0.05)$. In fact, $40 \%$ of the Barb horses and $26.6 \%$ of the Arabian horses were positives.

\section{nPCR amplification}

A. phagocytophilum DNA was detected by nested PCR in 8 blood samples among 60 tested horses (13\%), including 2 horses from Sejnane, 4 from Ghardimaou and two from Ain Draham. These 8 horses were between 7 and 21 years old and included the two different breeds. Breed $\left(\chi^{2}=0.02 ; \mathrm{P}=0.89\right)$ and age $\left(\chi^{2}=0.94 ; \mathrm{P}=0.3\right)$ differences were non-significant. Four of the 8 positive horses were also seropositive for A. phagocytophilum, but 4 horses infected with $A$. phagocytophilum were IFA negative. The concordance rate of $A$. phagocytophilum detection between IFA and nPCR was -0.07 .

Table 1 Genetic variations detected in partial sequences of 16S rRNA gene of Anaplasma phagocytophilum detected in horses and ticks

\begin{tabular}{|c|c|c|c|c|c|c|c|c|c|c|c|c|c|c|c|}
\hline \multirow[b]{2}{*}{ GenBank accession number } & \multirow[b]{2}{*}{ Source of detection } & \multicolumn{14}{|c|}{ Nucleotide position $^{2}$} \\
\hline & & 11 & 23 & 28 & 73 & 118 & 130 & 234 & 246 & 249 & 276 & 284 & 287 & 302 & 397 \\
\hline JN990106 & Tick & C & $\mathrm{T}$ & G & G & G & C & $\mathrm{T}$ & $\mathrm{T}$ & A & A & $\mathrm{T}$ & C & C & $A$ \\
\hline JX121282 & Tick & * & * & * & * & * & * & * & * & * & * & * & * & * & $*$ \\
\hline$J X 121283$ & Tick & $*$ & * & $*$ & * & * & * & * & $\underline{w}$ & $\underline{\mathbf{R}}$ & * & * & * & * & $*$ \\
\hline$J X 121284$ & Horse & * & * & $*$ & * & * & * & $\underline{\mathrm{C}}$ & $*$ & * & * & * & * & * & $*$ \\
\hline$J X 121285$ & Horse & * & * & $*$ & * & $\underline{A}$ & * & * & * & * & * & * & * & * & $*$ \\
\hline$J X 121286$ & Horse & * & * & * & * & * & * & * & * & * & * & * & * & $\underline{T}$ & $*$ \\
\hline JX121287 & Horse & $\underline{\mathrm{T}}$ & * & * & * & * & * & * & * & * & $\underline{\mathrm{T}}$ & * & * & * & $*$ \\
\hline JX121288 & Horse & * & $\underline{C}$ & * & $\underline{\mathbf{R}}$ & * & * & * & * & * & * & * & * & * & $*$ \\
\hline$J X 121289$ & Horse & * & * & * & * & * & * & * & * & * & * & * & * & * & $*$ \\
\hline JX121290 & Horse & * & * & $\underline{A}$ & * & * & $\underline{T}$ & * & * & * & * & * & $\underline{T}$ & * & $*$ \\
\hline$J X 121291$ & Horse & * & * & $*$ & * & * & * & * & * & * & * & $\underline{\mathbf{G}}$ & * & * & $\underline{T}$ \\
\hline
\end{tabular}

${ }^{1}$ The sequences of the genotypes obtained in this work [GenBank: JX121282-JX121291] were compared to the sequence previously reported in China [GenBank JN990106]. ${ }^{2}$ Unique nucleotides are indicated with bold underlined letters. Conserved nucleotide positions are indicated with an asterisk. 
Only 154 unfed ticks (engorged specimens were discarded) were screened $(130 \mathrm{H}$. marginatum, $16 \mathrm{H}$. excavatum and $8 R$. bursa) for $A$. phagocytophilum DNA by nPCR. Bacterial DNA was present in three male H. marginatum, detected as a single band of the appropriate size by nPCR using primers specific for $A$. phagocytophilum.

\section{Sequencing data}

Ten different variants in sequences of the partial $16 \mathrm{~S}$ rRNA gene of $A$. phagocytophilum are known to occur [GenBank: JX121282-JX121291]. Only two sequences were obtained from tick-derived amplicons [GenBank: JX121282, JX121283]. The remaining DNA extracted from $H$. marginatum male ticks led to a weak positive signal in PCR and was not sequenced.

The two sequences for the tick-derived amplicons [GenBank: JX121282, JX121283] differed from each other by 2 nucleotide positions (Table 1). One sequence [GenBank: JX121282] was 100\% similar to the GenBank JN990106 sequence derived from adult Ixodes persulcatus collected from grass in China [17]. The second sequence [GenBank: JX121283] was 99\% identical to the sequence identified in ticks in China [GenBank: JN990106].

The partial sequences of the amplicons derived from the 8 positive horses were submitted to the GenBank database under accession numbers [GenBank: JX121284-JX121291] (Table 1). BLAST search of the horse derived sequences against GenBank revealed 99\% similarity with Anaplasma phagocytophilum isolate NE16S-2 [GenBank: JN990106] except one sequence [GenBank: JX121289] which is identical to JN990106 (Table 1). Sequences differed by 12 nucleotide positions (Table 1).

Alignment of the ten partial 16S rRNA gene sequences revealed 9 different sequence variants with 14 distinctions of nucleotide positions (Table 1). Two of these different strains revealed [GenBank: JX121283, JX121288] mixed profiles of $A$. phagocytophilum strains with superposition of SNPs on the same sequence (Table 1). SNPs were confirmed by sequencing twice the corresponding amplicons by the ge9F and ge 2 primers.

\section{Discussion}

A. phagocytophilum, the causative agent of granulocytic ehrlichiosis, affects several species of wild and domesticated mammals, including horses. Our investigation shows that $A$. phagocytophilum infects horses in Tunisia.

Of 60 horses screened by IFA, 40 were seroreactive with A. phagocytophilum antigen, showing that horses in Tunisia are exposed to $A$. phagocytophilum. The high rate of $A$. phagocytophilum antibody prevalence in healthy animals in the visited farms indicates that the horses may have developed subclinical A. phagocytophilum infection. A. phagocytophilum seroprevalence (67\%) in the present study was higher than in previous surveys conducted in France (11.3\%) [18], Spain (6.52\%) [19], Italy $(7.79,16.89 \%, 17.03,9 \%)[20-23]$, Sweden $(16.7 \%)$ [24] and Denmark (22.3\%) [25]. Other studies conducted in the US and Asia also revealed lower seroprevalence [26-29]. However, our result showed a significant seroprevalence difference between Arabian and Barb breeds. This could be attributed to the fact that the latter horses, used for several forest duties, were more exposed to ticks.

Serological methods are often used to diagnose anaplasmosis mainly in investigations involving large numbers of animals. But these tests cannot provide sufficient information for a diagnosis of the disease [30]. To overcome the limitation of the serological test, $16 \mathrm{~S}$ rDNA based nested-PCR was used to obtain molecular evidence of $A$. phagocytophilum infection. In addition, partial sequencing of the detected 16S rRNA gene of $A$. phagocytophilum confirmed the nested-PCR results. Thus PCR-based molecular assays are powerful tools for diagnosing infectious diseases and for detecting bacterial agents in clinical cases and arthropod vector samples alike. These assays were instrumental in identifying $A$. phagocytophilum [1,31].

Using nested-PCR, among 60 analyzed animals, $A$. phagocytophilum DNA was detected in eight horses for the first time in Tunisia. The rate of PCR-positive horse samples (13\%), drawn from the humid zone of Tunisia, is similar to that on the island of Sardinia (15\%) [6] but is higher than previous surveys conducted in Central Italy (8\%) [22].

The comparison of serological and molecular results shows that there is no concordance between the two tests used. A serologically positive test against a PCRnegative result could correspond to a past infection. Among PCR-Anaplasma positive horses $(n=8)$, only 4 had antibodies reactive with $A$. phagocytophilum. The remaining horses may have been sampled very early in the course of infection before antibody response had occurred or be related to a failure in responding to acute Anaplasma infection. In naturally infected horses, immunity persists for at least two years and does not appear to depend on latent infection or carrier status [32]. It has also been demonstrated that indirect fluorescent antibody titers to $A$. phagocytophilum persist for approximately 300 days after experimental infection [26] and animals tend to become serologically negative progressively, unless reinfections intervene.

Regarding the entomological survey, ticks infesting tested horses belong to three different species (H. marginatum, $H$. excavatum and $R$. bursa). $H$. marginatum was the most abundant tick species in the collected 
samples. All of these three tick species are active in spring [11], which was when we did our sampling. This led us to hypothesize that $H$. marginatum can be involved in transmitting $A$. phagocytophilum to horses. Indeed, the PCR study of these specimens $(\mathrm{n}=154)$ revealed the presence of $A$. phagocytophilum in three $H$. marginatum ticks, but does not of course prove that the species can transmit the infection. This low number of positive PCR results could depend on the vector competence of the tested tick species, the time of year, the geographical region and the limited bacteraemia of horses, which might significantly reduce tick infectivity. In previous studies we also detected $A$. phagocytophilum infections in dogs and in 3\% of Hyalomma detritum and $1 \%$ of Ixodes ricinus ticks [8,9]. The latter tick species is considered to be the main vector of $A$. phagocytophilum in Europe. The absence of I. ricinus ticks on the horses that we examined could be attributed to the collection season, as this tick is active in Tunisia from September to March, that is, during autumn and winter [11].

However, A. phagocytophilum is spread widely in the northern hemisphere [33] and has been detected by PCR in Ixodes ricinus in almost all countries in Europe [34]. In Germany, the overall prevalence ranges from $1.0 \%$ to 4.5\% [35,36]. The overall prevalence in Europe ranges from $0.25 \%$ in Scotland to $57.1 \%$ in Italy $[37,38]$ with great variation in every country: from $0.4 \%$ to $15 \%$ in France [39,40], from $3 \%$ to $57 \%$ in Italy $[38,41,42]$, from $0.25 \%$ to $2 \%$ in Scotland [37], $3 \%$ in Estonia [43], from $5.1 \%$ to $8.7 \%$ in Austria $[44,45]$, from $0.5 \%$ to $2.2 \%$ in Switzerland [46-48], up to $40.5 \%$ in Denmark [49] and up to $14 \%$ in various Eastern European countries [50-54].

There have also been reports about the detection of $A$. phagocytophilum in I. spinipalpis and I. dentatus in the US [55,56]. In Asia, A. phagocytophilum has been detected in the hard ticks I. persulcatus and I. ovatus [57,58]. Apart from the genus Ixodes, A. phagocytophilum has also been detected in Dermacentor variabilis in California and D. silvarum in China [59,60].

Seeking IgG against A. phagocytophilum provides an excellent screening method to explore the circulation of the bacteria; PCR therefore remains a critical tool for a faster and earlier diagnosis. Positive serological testing and DNA detection by PCR are both evidence of $A$. phagocytophilum circulation in Tunisia. Even clinical anaplasmosis in horses probably remains under-diagnosed in Tunisia, as most horses recover spontaneously and clinical signs resemble those caused by infections by such other pathogens as Borrelia burgdorferi, Babesia caballi, Theileria equi, equine herpesvirus, equine infectious anaemia virus, equine arteritis virus and Leptospiraceae [61]. Similarly, an earlier study of $A$. phagocytophilum has indicated that up to $50 \%$ of seropositive horses, in endemic areas, have a subclinical infection [26]. It is assumed that clinical equine granulocytic anaplasmosis is an overlooked condition in most of Europe, as most horses recover spontaneously and clinicians do not examine them [62].

\section{Conclusions}

This study marks the first report providing serological and molecular evidence of $A$. phagocytophilum infection in horses and ticks in Tunisia and should therefore be of interest to veterinary clinicians regarding the possible existence of clinical cases of equine anaplasmosis. Given the zoonotic aspect of $A$. phagocytophilum, physicians should also be informed of the presence of this bacterium in Tunisia. No serologic evidence of exposure to $A$. phagocytophilum has been reported in humans in $\mathrm{Tu}$ nisia to date and this bacterium has not yet been isolated or detected by PCR in clinical cases in Tunisia. In addition, the results show that more than one variant of A. phagocytophilum, using partial $16 \mathrm{~S}$ rRNA gene, seems to be involved in equine granulocytic anaplasmosis in Tunisia Furthermore, the zoonotic importance of $A$. phagocytophilum lends support to the need to increase the surveillance of the presence of this pathogen in Tunisia.

\section{Competing interests}

The authors declare that they have no competing interests.

\section{Authors' contributions}

YM carried out the serological, molecular genetic studies, the sequence alignment, the statistical analysis and drafted the manuscript. HY carried out the serological assay. AG participated in the design of the study and sample horse collection. $A B$ conceived of the study, and participated in its design and coordination, helped to draft the manuscript and sample horse collection. All authors read and approved the final manuscript.

\section{Acknowledgements}

We are grateful to Dr. Eremeeva M. (CDC/OID/NCEZID), Dr. Uilenberg G., Dr. Ghram A. (IP Tunis) and Glassman D. for constructive comments on early drafts of the manuscript. We would like to thank Dr. Leila Saieh and Dr. Ridha Ben Omrane for their help in field work. We also would like to express thanks to Dr Postic D. (I.P.P.) for providing positive controls. This work was supported by a grant from the Ministry for Higher Education, Scientific Research, and Technology in Tunisia.

\section{Author details}

${ }^{1}$ Laboratoire d'épidémiologie et microbiologie vétérinaire, service d'entomologie médicale, Institut Pasteur de Tunis, Tunis 1002, Tunisia.

${ }^{2}$ Université Tunis El-Manar, Tunis, Tunisia. ${ }^{3}$ Service pathologie médicale des équidés et des carnivores, Ecole nationale de medicine vétérinaire de Sidi Thabet, Tunis 2002, Tunisia. ${ }^{4}$ Université de la Manouba, Manouba, Tunisia.

Received: 21 June 2012 Accepted: 24 August 2012

Published: 30 August 2012

\section{References}

1. Dumler JS, Barbet AF, Bekker CP, Dasch GA, Palmer GH, Ray SC, Rikihisa Y, Rurangirwa FR: Reorganization of genera in the families Rickettsiaceae and Anaplasmataceae in the order Rickettsiales: unification of some species of Ehrlichia with Anaplasma, Cowdria with Ehrlichia and Ehrlichia with Neorickettsia, descriptions of six new species combinations and designation of Ehrlichia equi and "HGE agent" as subjective synonyms of Ehrlichia phagocytophila. Int J Syst Evol Microbiol 2001, 51:2145-2165. 
2. Gribble DH: Equine ehrlichiosis. J Am Vet Med Assoc 1969, 155:462-469.

3. Korbutiak E, Schneiders D: Equine granulocytic ehrlichiosis in the UK. Vet Rec 1994, 135:387-388

4. Bermann F, Davoust B, Fournier PE, Brisou-Lapointe AV, Brouqui P: Ehrlichia equi (Anaplasma phagocytophila) chez un cheval adulte en France. Vet Rec 2002, 150(25):787-788.

5. Von Loewenich FD, Stumpf G, Baumgarten BU, Röllinghoff M, Dumler JS, Bogdan C: A Case of equine granulocytic ehrlichiosis provides molecular evidence for the presence of pathogenic Anaplasma phagocytophilum (HGE agent) in Germany. Eur J Clin Microbiol Infect Dis 2003, 22(5):303-305.

6. Alberti A, Zobba R, Chessa B, Addis MF, Sparagano O, Parpaglia MLP, Cubeddu T, Pintori G, Pittau M: Equine and Canine Anaplasma phagocytophilum Strains Isolated on the Island of Sardinia (Italy) are phylogenetically related to pathogenic strains from the United States. Appl Env Microbiol 2005, 71:6122-6418.

7. Thomas RJ, Dumler JS, Carlyon JA: Current management of human granulocytic anaplasmosis, human monocytic ehrlichiosis and Ehrlichia ewingii ehrlichiosis. Expert Rev Anti Infect Ther 2009, 7:709-722.

8. Sarih M, M'ghirbi Y, Bouattour A, Gern L, Baranton G, Danièle P: Detection and identification of Ehrlichia spp. in Ticks collected in Tunisia and Morocco. J Clin Microbiol 2005, 43(3):1127-1132.

9. M'ghirbi Y, Ghorbel A, Amouri M, Nebaoui A, Haddad S, Bouattour A: Clinical, serological, and molecular evidence of ehrlichiosis and anaplasmosis in dogs in Tunisia. Parasitol Res 2009, 104(4):767-774

10. Nowak M, Cieniuch S, Stańczak J, Siuda K: Detection of Anaplasma phagocytophilum in Amblyomma flavomaculatum ticks (Acari: Ixodidae) collected from lizard Varanus exanthematicus imported to Poland. Exp Appl Acarol 2010, 51(4):363-371.

11. Bouattour A, Darghouth MA, Daoud A: Distribution and ecology of ticks (Acari: Ixodidae) infesting livestock in Tunisia: an overview of eight years field collection. Parassitologia 1999, 41:5-10

12. Bouattour A: Clé dichotomique et identification des tiques (Acari: Ixodidae) parasites du bétail au Maghreb. Arch Inst Pasteur Tunis 2002, 79:43-50.

13. Massung RF, Slater K, Owens JH, Nicholson WL, Mather TN, Solberg VB, Olson JG: Nested PCR assay for the detection of granulocytic ehrlichiae. J Clin Microbiol 1998, 36:1090-1095.

14. Hall TA: BioEdit: A user-friendly biological sequence alignment editor and analysis program for Windows 95/98/NT. Nucleic Acids Symp Ser 1999, 41:95-98.

15. Thompson JD, Higgins DG, Gibson TJ: ClustalW: improving the sensitivity of progressive multiple sequence alignment through sequence weighting, position-specific gap penalties and weight matrix choice. Nucleic Acids Res 1994, 22:4673-4680.

16. Cohen J: A coefficient of agreement for nominal scales. Edu Psychol Meas 1960, 20:37-46.

17. Li Y, Zuo S-Y, Tang K, Pu G-Q: Investigation on the infection of ticks with Anaplasma phagocytophilum in the Northeast China forest region from 2010 to 2011. Chin J Vector Biol and control 2012, 23(2):111-117.

18. Leblond A, Pradier S, Pitel PH, Fortier G, Boireau P, Chadoeuf J, Sabatier P: An epidemiological survey of equine anaplasmosis (Anaplasma phagocytophilum) in southern. Rev Sci Tech 2005, 24(3):899-908.

19. Amusategui I, Sainz A, Tesouro MA: Serological evaluation of Anaplasma phagocytophilum infection in livestock in northwestern Spain. Ann N Y Acad Sci 2006, 1078:487-490.

20. Torina A, Vicente J, Alongi A, Scimeca S, Turla R, Nicosie S, Di Marco V, Caracappa $S$, de la Fuente J: Observed prevalence of tick-borne pathogens in domestic animals in Sicily, Italy during 2003-2005. Zoonoses Santé Publ 2007, 54(1):8-15.

21. Ebani V, Cerri D, Fratini F, Ampola M, Andreani E: Seroprevalence of Anaplasma phagocytophilum in domestic and wild animals from central Italy. New Microbiol 2008, 31(3):371-375.

22. Passamonti F, Veronesi F, Cappelli K, Capomaccio S, Coppola G, Marenzoni ML, Piergili FD, Verini SA, Coletti M: Anaplasma phagocytophilum in horses and ticks: a preliminary survey of Central Italy. Comp Immunol Microbiol Infect Dis 2010, 33(1):73-83.

23. Giudice E, Giannetto C, Furco V, Alongi A, Torina A: Anaplasma phagocytophilum seroprevalence in equids: a survey in Sicily (Italy). Parasitol Res 2012, 111(2):951-955

24. Egenvall A, Franzén P, Gunnarsson A, Engvall EO, Vågsholm I, Wikström UB, Artursson K: Cross-sectional study of the seroprevalence to Borrelia burgdorferi sensu lato and granulocytic Ehrlichia spp. and demographic, clinical and tick-exposure factors in Swedish horses. Prev Vet Med 2001, 49(3-4):191-208

25. Hansen MG, Christoffersen M, Thuesen LR, Petersen MR, Bojesen AM: Seroprevalence of Borrelia burgdorferi sensu lato and Anaplasma phagocytophilum in Danishhorses. Acta Vet Scand 2010, 18:52-53.

26. Madigan J, Hietala A, Chambers S: Seroepidemiologic survey of antibodies to Ehrlichia equi in horses in northern California. J Am Vet Med Assoc 1990, 196:1962-1964.

27. Bullock PM, Ames TR, Robinson RA, Greig B, Mellencamp MA, Dumler JS: Ehrlichia equi infection of horses from Minnesota and Wisconsin: detection of seroconversion and acute disease investigation. J Vet Int Med 2000, 14:252-257.

28. Teglas M, Matern E, Lein S, Foley P, Mahan SM, Foley J: Ticks and tickborne disease in Guatemalan cattle and horses. Vet Parasitol 2005, 131(1-2):119-127.

29. Chahan B, Jian Z, Xuan X, Sato Y, Kabeya H, Tuchiya K, Itamoto K, Okuda M, Mikami T, Maruyama S, Inokuma H: Serological evidence of infection of Anaplasma and Ehrlichia in domestic animals in Xinjiang Uygur Autonomous Region area, China. Vet Parasitol 2005, 134(3-4):273-278.

30. Rikihisa Y: The tribe Ehrlichiae and Ehrlichial diseases. Clin Microbiol Rev 1991, 4:286-308

31. Chen SM, Dumler J, Bakken J, Walker D: Identification of a granulocytotropic Ehrlichia species as the etiologic agent of human disease. J Clin Microbiol 1994, 32:589-595.

32. Sellon DC: Miscellaneous parasitic diseases. In Equine infectious diseases Edited by Sellon DC, Long MT. St. Louis: Saunders Elsevier; 2007: 473-480.

33. Teglas MB, Foley J: Differences in the transmissibility of two Anaplasma phagocytophilum strains by the North American tick vector species, Ixodes pacificus and Ixodes scapularis (Acari: Ixodidae). Exp Appl Acarol 2006, 38:47-58.

34. Strle F: Human granulocytic ehrlichiosis in Europe. Int J Med Microbiol 2004, 293(Suppl 37):27-35.

35. Hartelt K, Oehme R, Frank H, Brockmann SO, Hassler D, Kimmig P: Pathogens and symbionts in ticks: prevalence of Anaplasma phagocytophilum (Ehrlichia sp.), Wolbachia sp., Rickettsia sp., and Babesia sp. in Southern Germany. Int J Med Microbiol 2004, 293(Suppl 37):86-92.

36. Leonhard S: Untersuchungen zur Häufigkeit von. Borrelia burgdorfer sensu lato, Anaplasma phagocytophilum und Babesia spp. In Ixodes ricinus aus Bayern und BadenWürttemberg. Dissertation. Germany: LudwigMaximilians-University München; 2005.

37. Alberdi MP, Walker AR, Paxton EA, Sumption KJ: Natural prevalence of infection with Ehrlichia (Cytoecetes) phagocytophila of Ixodes ricinus ticks in Scotland. Vet Parasitol 1998, 78(4):203-213.

38. Mantelli B, Pecchioli E, Hauffe HC, Rosà R, Rizzoli A: Prevalence of Borrelia burgdorferi s.l. and Anaplasma phagocytophilum in the wood tick Ixodes ricinus in the Province of Trento, Italy. Eur J Clin Microbiol Infect Dis 2006, 25:737-739.

39. Ferquel E, Garnier M, Marie J, Bernède-Bauduin C, Baranton G, Pérez-Eid C, Postic D: Prevalence of Borrelia burgdorferi sensu lato and Anaplasmataceae members in Ixodes ricinus ticks in Alsace, a focus of Lyme borreliosis endemicity in France. App/ Environ Microbiol 2006, 72:3074-3078

40. Halos L, Vourc'h G, Cotte V, Gasqui P, Barnouin J, Boulous HJ, Vayssier TM: Prevalence of Anaplasma phagocytophilum, Rickettsia sp. and Borrelia burgdorferi sensu lato DNA in Questing Ixodes ricinus Ticks from France. Ann N Y Acad Sci 2006, 1078:316-319.

41. Cinco M, Padovan D, Murgia R, Maroli M, Frusteri L, Heldtander M, Johansson KE, Engvall EO: Coexistence of Ehrlichia phagocytophila and Borrelia burgdorferi sensu lato in Ixodes ricinus ticks from Italy as determined by 16S rRNA gene sequencing. J Clin Microbiol 1997, 35:3365-3366

42. Piccolin G, Benedetti G, Doglioni C, Lorenzato C, Mancuso S, Papa N, Pitton L, Ramon MC, Zasio C, Bertiato G: A Study of the Presence of $B$. burgdorferi, Anaplasma (Previously Ehrlichia) phagocytophilum, Rickettsia, and Babesia in Ixodes ricinus Collected within the Territory of Belluno, Italy. Vector Borne Zoonotic Dis 2006, 6:24-31. 
43. Mäkinen J, Vuorinen I, Oksi J, Peltomaa M, He Q, Marjamäki M, Viljanen MK: Prevalence of granulocytic Ehrlichia and Borrelia burgdorferi sensu lato in Ixodes ricinus ticks collected from southwestern Finland and from Vormsi Island in Estonia. APMIS 2003, 111:355-362.

44. Sixl W, Petrovec M, Marth E, Wüst G, Stünzer D, Schweiger R, Avsic-Zupanc $\mathrm{T}$ : Investigation of Anaplasma phagocytophila Infections in Ixodes ricinus and Dermacentor reticulatus ticks in Austria. Ann N Y Acad Sci 2003, 990:94-97.

45. Polin H, Hufnagl P, Haunschmid R, Gruber F, Ladurner G: Molecular Evidence of Anaplasma phagocytophilum in Ixodes ricinus Ticks and Wild Animals in Austria. J Clin Microbiol 2004, 42:2285-2286.

46. Leutenegger CM, Pusterla N, Mislin CN, Weber R, Lutz H: Molecular evidence of coinfection of ticks with Borrelia burgdorferi sensu lato and the human granulocytic ehrlichiosis agent in Switzerland. J Clin Microbiol 1999, 37:3390-3391.

47. Pusterla N, Leutenegger CM, Huder JB, Weber R, Braun U, Lutz H: Evidence of the human granulocytic ehrlichiosis agent in Ixodes ricinus ticks in Switzerland. J Clin Microbiol 1999, 37:1332-1334.

48. Liz JS, Anderes L, Sumner JW, Massung RF, Gern L, Rutti B, Brossard M: PCR detection of granulocytic ehrlichiae in Ixodes ricinus ticks and wild small mammals in western Switzerland. J Clin Microbiol 2000, 38:1002-1007.

49. Skarphédinsson S, Lyholm BF, Ljungberg M, Sogaard P, Kolmos HJ, Nielsen LP: Detection and identification of Anaplasma phagocytophilum, Borrelia burgdorferi, and Rickettsia helvetica in Danish Ixodes ricinus ticks. APMIS 2007, 115:225-230.

50. Petrovec M, Sumner JW, Nicholson WL, Childs JE, Strle F, Barlic J, LotricFurlan S, Avsic ZT: Identity of ehrlichial DNA sequences derived from Ixodes ricinus ticks with those obtained from patients with human granulocytic ehrlichiosis in Slovenia. J Clin Microbiol 1999, 37:209-210.

51. Derdáková M, Halanova M, Stanko M, Stefancikova A, Cislakova L, Pet'ko B: Molecular evidence for Anaplasma phagocytophilum and Borrelia burgdorferi sensu lato in Ixodes ricinus ticks from eastern Slovakia. Ann Agric Environ Med 2003, 10:269-271.

52. Hulínská D, Langrová K, Pejcoch M, Pavlásek I: Detection of Anaplasma phagocytophilum in animals by real-time polymerase chain reaction. APMIS 2004, 112:239-247.

53. Stańczak J, Gabre RM, Kruminis-Lozowska W, Racewicz M, Kubica-Biernat B: Ixodes ricinus as a vector of Borrelia burgdorferi sensu lato, Anaplasma phagocytophilum and Babesia microti in urban and suburban forests. Ann Agric Environ Med 2004, 11:109-114.

54. Koči J, Movila A, Taragel'ová V, Toderas I, Uspenskaia I, Derdáková M, Labuda M: First report of Anaplasma phagocytophilum and its co-infections with Borrelia burgdorferi sensu lato in Ixodes ricinus ticks (Acari: Ixodidae) from Republic of Moldova. Exp Appl Acarol 2007, 41:147-152.

55. Zeidner NS, Burkot TR, Massung R, Nicholson WL, Dolan MC, Rutherford JS, Biggerstaff BJ, Maupin GO: Transmission of the agent of human granulocytic ehrlichiosis by Ixodes spinipalpis ticks: evidence of an enzootic cycle of dual infection with Borrelia burgdorferi in Northern Colorado. J Infect Dis 2000, 182:616-619.

56. Goethert HK, Telford SR: Enzootic transmission of the agent of human granulocytic ehrlichiosis among cottontail rabbits. AmJTrop Med Hyg 2003, 68:633-637.

57. Cao WC, Zhoa QM, Zhang PH, Dumler JS, Zhang XT, Fang LQ, Yang H: Granulocytic Ehrlichiae in Ixodes persulcatus Ticks from an Area in China Where Lyme Disease is Endemic. J Clin Microbiol 2000, 38:4208-4210.

58. Ohashi N, Inayoshi M, Kitamura K, Kawamori F, Kawaguchi D, Nishimura Y, Naitou H, Hiroi M, Masuzawa T: Anaplasma phagocytophilum-infected ticks, Japan. Emerg Inf Dis 2005, 11:1780-1783.

59. Holden K, Boothby JT, Anand S, Massung RF: Detection of Borrelia burgdorferi, Ehrlichia chaffeensis, and Anaplasma phagocytophilum in ticks (Acari: Ixodidae) from a coastal region of California. J Med Entomol 2003, 40:534-539.

60. Cao WC, Zhan L, He J, Foley JE, DE Vlas SJ, Wu XM, Yang H, Richardus JH, Habbema JD: Natural Anaplasma phagocytophilum infection of ticks and rodents from a forest area of Jilin province China. AmJTrop Med Hyg 2006, 75:664-668.
61. Salvagni CA, Dagnone AS, Gomes TS, Mota JS, Andrade JM, Baldani CD, Machado RZ: Serologic evidence of equine granulocytic anaplasmosis in horses from central West Brazil. Rev Bras Parasitol Vet 2010, 19(3):135-140

62. Butler CM, Nijhof AM, Jongejan F, Van der Kolk JH: Anaplasma phagocytophilum infection in horses in the Netherlands. Vet Rec 2008, 162:218-219.

doi:10.1186/1756-3305-5-180

Cite this article as: M'ghirbi et al:: Anaplasma phagocytophilum in horses and ticks in Tunisia. Parasites \& Vectors 2012 5:180.

\section{Submit your next manuscript to BioMed Central and take full advantage of:}

- Convenient online submission

- Thorough peer review

- No space constraints or color figure charges

- Immediate publication on acceptance

- Inclusion in PubMed, CAS, Scopus and Google Scholar

- Research which is freely available for redistribution

Submit your manuscript at www.biomedcentral.com/submit
C) BioWed Central 